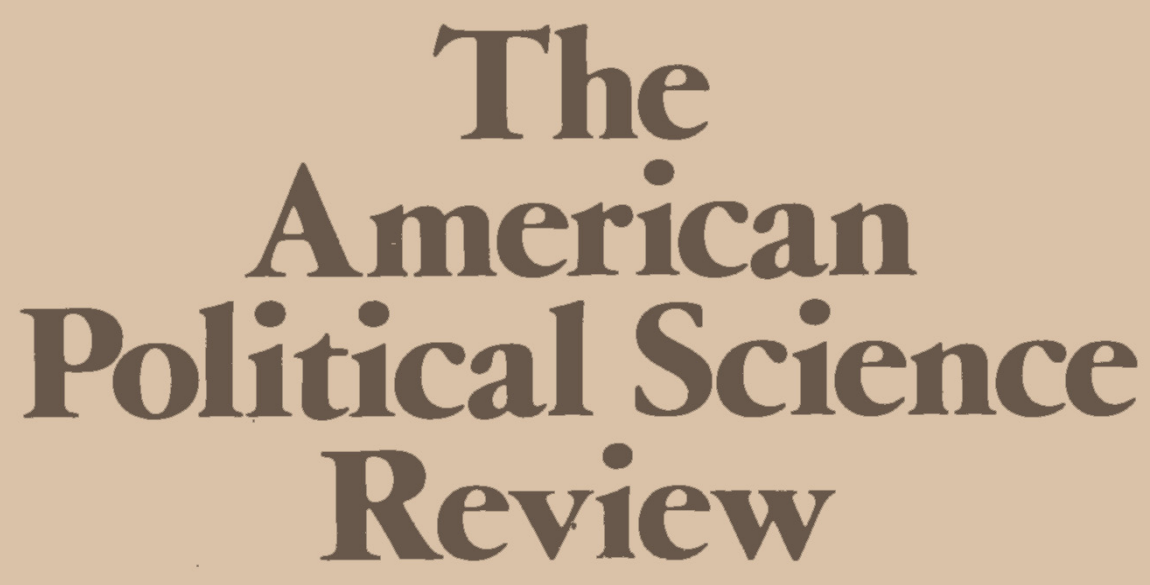

Published Quarterly by The American Political Science Association 
Iere's a

cover story

that will

make a big

diflerence

in American

government

courses...
Coming in October...

HILSMAN's

TO GOVERN AMERICA:

\section{Politics, Power, and Policy Making}

Roger Hilsman gives students a working perspective on government based on the 3 p's-politics, power, and policy. He focuses on policy making as a political process and he shows who exercises power at all levels of the process. It's a dynamic perspective acquired in his career from West Point graduate to Columbia University professor via distinguished service in the Army, the State Department, the Congressional Research Service, and George Washington and Johns Hopkins universities, as well as in running for Congress.

TO GOVERN AMERICA is as lively as it is thorough in its coverage of the inputs and outputs of government. Chapters progress from the "proximate policy makers" (those closest to decision making-the President, members of Congress, judges, bureaucrats, and appointees) to the "second ring" (interest groups, the press, and parties); and then to the electorate. Other unique features: analyses of political appointees and the national security bureaucracies; examination of questions concerning a power elite and the ability of the American political system to cope with post-industrial problems. INSTRUCTOR'S MANUAL. 656 pages, \$14.95/tentative. ISBN 0-06-042838-4.

\section{Examine these recent successes before you adopt for second semester...}

\author{
ROBERT L. LINEBERRY
}

\section{AMERICAN PUBLIC POLICY:}

\section{What Government Does and What Difference It Makes}

The twin themes of policy analysis and the application of policy to key political issues enliven this introduction to public policy. The text first discusses theories and methods of domestic policy analysis and then applies these techniques in four areas: cities, crime, inequality, and the management of scarcity. Other contemporary issues are discussed within this overall context. 296 pages. $\$ 7.95 /$ paper. January 1978. ISBN 0-06-044013-9.

\section{ROBERT L. LINEBERRY \& IRA SHARKANSKY URBAN POLITICS AND PUBLIC POLICY Third Edition}

This text reflects a continuing emphasis on the policy choices in the urban community that shape the quality of urban life. The authors provide extensive treatments of mass politics and elite decision making in the urban context. This new edition includes recent developments in school busing, the rise of the sun-belt cities, fiscal crises in New York and other cities, changes in the post-Daley Chicago machine, and the growing role of federal courts in constraining urban governments. 416 pages; $\$ 10.95 /$ paper. February 1978. ISBN 0-06-044029-5.

PRICES SUBJECT TO CHANGE WITHOUT NOTICE. Prices quoted by Harper \& Row are suggested list prices only and in no way reflect the prices at which these books may be sold by suppliers other than Harper \& Row.

To request examination copies, please write to Alec Lobrano, Dept. 604. Include course title, present text, and enrollment.

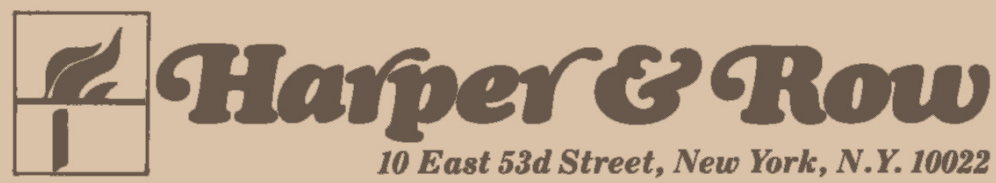




\section{The American Political Science Review}

Vol. 72

September, 1978

No. 3

TABLE OF CONTENTS

Approval Voting

Steven J. Brams and Peter C. Fishburn

Stability, Coalitions and Schisms in Proportional Representation Systems

M. L. Balinski and H.P. Young

The Structure of "Politics"

859

Fred M. Frohock

Alienation and Justice in the Market

Arthur DiQuattro

Comedy in Callipolis: Animal Imagery in the Republic

888

Arlene W. Saxonhouse

Selecting Cases for Supreme Court Review: An Underdog Model

902

S. Sidney Ulmer

Judges' Role Orientations, Attitudes, and Decisions: An Interactive Model

James L. Gibson

Bickel's Constitution: The Problem of Moderate Liberalism

Robert K. Faulkner

A Reactive Linkage Model of the U.S. Defense Expenditure Policy-Making Process

Charles W. Ostrom, Jr.

The Corruption of a State

958

J. Patrick Dobel

Political Corruption in America

John G. Peters and Susan Welch

Policy Support within a Target Group: The Case of School Desegregation

Douglas S. Gatlin, Micheal Giles, and Everett F. Cataldo

Analyzing Diffusion and Contagion Effects: The Urban Disorders of the 1960s

Manus I. Midlarsky

Communications

Review Essay-The Political Economy of Charles E. Lindblom

Office of publication: Curtis Reed Plaza, Menasha, Wisconsin.

Second class postage paid at Washington, D.C., and at additional mailing offices.

Composition by TypoGraphics, Columbia, Maryland.

Printed in the United States of America by George Banta Company, Inc., Menasha, Wisconsin.

Copyright 1978, by The American Political Science Association. 
Robert Axelrod, ed., Structure of Decision: The Cognitive Maps of Political Elites. Margaret G. Hermann. p1017. Brian Barry, ed., Power and Political Theory: Some European Perspectives. Marvin E. Olsen. p1018.

A. S. Cohan, Theories of Revolution: An Introduction. Ronald J. Herring. p1019.

Richard E. Flathman, The Practice of Rights. Robert Booth Fowler. p1020.

Charles Frankel, ed., Controversies and Decisions: The Social Sciences and Public Policy. Eugene J. Meehan. p. 1021.

Paul N. Goldstene, The Collapse of Liberal Empire: Science and Revolution in the Twentieth Century. William E. Connolly. p1022.

Phillip M. Gregg, ed., Problems of Theory in Policy Analysis. Bryan T. Downes. p.1023.

R. J. Halliday, John Stuart Mill. Joseph Hamburger. p. 1024.

Emmanuel Hansen, Frantz Fanon: Social and Political Thought. James Miller. p. 1025.

F. A. Hayek, Law, Legislation and Liberty, Volume 2: The Mirage of Social Justice. Sanford Levinson. p. 1026.

Albert O. Hirschman, The Passions and the Interests: Political Arguments for Capitalism before Its Triumph. Peter G. Stillman. p. 1027.

Ted Honderich, Political Violence: A Philosophical Analysis of Terrorism. Mulford Q. Sibley. p. 1028.

Morton A. Kaplan, Justice, Human Nature, and Political Obligation; and Morton A. Kaplan, Alienation and Identification. David Miller. p. 1029.

Melvin J. Lasky, Utopia and Revolution: On the Origins of a Metaphor, or Some Illustrations of the Problem of Political Temperament and Intellectual Climate and How Ideas, Ideals, and Ideologies Have Been Historically Related. Paul Thomas. p. 1031.

Allan W. Lerner, The Politics of Decision-Making: Strategy, Cooperation, and Conflict. Philip H. Melanson. p. 1032.

David Loye, The Leadership Passion: A Psychology of Ideology. Theodore R. Malloch. p. 1033.

James G. March and Johan P. Olsen et al., Ambiguity and Choice in Organizations. Lawrence B. Mohr. p. 1033.

Paul Nejelski, ed., Social Research in Conflict with Law and Ethics. James D. Carroll. p. 1035.

James H. Nichols, Jr., Epicurean Political Philosophy: The De Rerum Natura of Lucretius. William Mathie. p. 1036.

N. K. O'Sullivan, Conservatism. Raleigh W. Smith, Jr. p. 1038.

S. S. Prawer, Karl Marx and World Literature. Theodore Mills Norton. p. 1038.

Martin Rein, Social Science and Public Policy. Kenneth M. Dolbeare. p. 1039.

Barbara Salert, Revolutions and Revolutionaries: Four Theories. Adam Przeworski. p. 1040.

Robert N. Spadaro, Thomas R. Dye, Robert T. Golembiewski, Murray S. Stedman, and L. Harmon Zeigler, The Policy Vacuum: Toward a More Professional Political Science. Richard L. Pattenaude.p. 1042.

Andrew von Hirsch, Doing Justice: The Choice of Punishments. George F. Cole. p. 1043.

Dale Vree, On Synthesizing Marxism and Christianity. Dante Germino. p. 1044.

Robert Paul Wolff, Understanding Rawls: A Reconstruction and Critique of A Theory of Justice. Robert $\mathrm{L}$. Simon. p. 1044.

Paul R. Abramson, The Political Socialization of Black Americans: A Critical Evaluation of Research on Efficacy and Trust. James W. Clarke, p. 1046.

Herbert E. Alexander, ed., Campaign Money: Reform and Reality in the States. Robert Agranoff. p. 1047.

Herbert E. Alexander, Financing Politics: Money, Elections and Political Reform. Delmer D. Dunn. p. 1049.

Stanley D. Bachrack, The Committee of One Million: "China Lobby" Politics, 1953-1971. Earl Latham. p. 1050.

Jack Bass and Walter DeVries, The Transformation of Southern Politics: Social Change and Political Consequence Since 1945. Charles Press. p. 1051.

David A. Caputo and Richard L. Cole, eds., Revenue Sharing: Methodological Approaches and Problems Steven A. Waldhorn. p. 1052.

William G. Colman, Cities, Suburbs and States: Governing and Financing Urban America. Robert L. Bish. p.1054. Thomas E. Cronin, The State of the Presidency. Lester G. Seligman. p. 1054.

Roger H. Davidson and Walter J. Oleszek, Congress Against Itself. Barbara Sinclair. p. 1056.

Peter F. Drucker, The Unseen Revolution: How Pension Fund Socialism Came to America. Theodore J. Lowi. p. 1056.

Morris P. Fiorina, Congress: Keystone of the Washington Establishment. Eric M. Uslaner. p. 1058.

Otis L. Graham, Jr., Toward a Planned Society: From Roosevelt to Nixon. Michael D. Reagan. p. 1059.

Andrew M. Greeley, The American Catholic: A Social Portrait. Kathleen A. Frankovic. p. 1059.

Hugh Heclo, A Government of Strangers: Executive Politics in Washington. Charles O. Jones. p. 1061.

Leo Hershkowitz, Tweed's New York: Another Look. Martin Shefter. p. 1062.

C. Richard Hofstetter, Bias in the News: Network Television News Coverage of the 1972 Election Campaign. Robert D. McClure. p. 1063. 
Donald L. Horowitz, The Courts and Social Policy; and Donald L. Horowitz, The Jurocracy: Government Lawyers, Agency Programs and Judicial Decisions. Joel B. Grossman. p. 1064.

Robert N. Katz, ed., Protecting Consumer Interests: Private Initiative and Public Response. Eric J. Novotny. p. 1067.

Jeane Kirkpatrick with Warren E. Miller, Elizabeth Douvan, William Crotty, Teresa Levitin, and Maureen Fiedler, The New Presidential Elite: Men and Women in National Politics. Denis G. Sullivan. p. 1068.

David Knoke, Change and Continuity in American Politics: The Social Bases of Political Parties. Charles D. Hadley. p. 1069.

Marc Karnis Landy, The Politics of Environmental Reform: Controlling Kentucky Strip Mining. Dieter Matthes. p. 1070.

Margaret Levi, Bureaucratic Insurgency: The Case of Police Unions. David T. Stanley. p. 1071.

Sar A. Levitan and Joyce K. Zickler, Too Little But Not Too Late: Federal Aid to Lagging Areas. Donald C. Menzel. p. 1072.

Theodore J. Lowi and Benjamin Ginsberg et al., Poliscide. Frederick M. Wirt. p. 1073.

Dale Mann, The Politics of Administrative Representation. Harmon Zeigler. p. 1074.

Spark M. Matsunaga and Ping Chen, Rule-Makers of the House. Bruce I. Oppenheimer. p. 1076.

George H. Nash, The Conservative Intellectual Movement in America: Since 1945. Robert A. Heineman. p. 1077.

Richard L. Rubin, Party Dynamics: The Democratic Coalition and the Politics of Change. Paul R. Abramson. p. 1078.

John E. Schwarz and L. Earl Shaw, The United States Congress in Comparative Perspective. John W. Kingdon. p. 1079.

Clarence N. Stone, Economic Growth and Neighborhood Discontent: System Bias in the Urban Renewal Program of Atlanta. Thomas J. An ton. p. 1080.

Richard J. Trilling, Party Image and Electoral Behavior. John Petrocik. p. 1081.

Stephen L. Wasby, Small Town Police and the Supreme Court: Hearing the Word. Neal Milner. p. 1082.

Martha Wagner Weinberg, Managing the State. Coleman B. Ransone, Jr. p. 1083.

Comparative Politics

Dennis Austin and Robin Luckham, eds., Politicians and Soldiers in Ghana 1966-1972. Jay E. Hakes. p. 1085.

Lewis Austin, ed., Japan: The Paradox of Progress. Lee W. Farnsworth. p. 1085.

Frederick C. Barghoorn, Détente and the Democratic Movement in the USSR. William Taubman. p. 1087.

Marguerite Ross Barnett, The Politics of Cultural Nationalism in South India. Stanley A. Kochanek. p. 1088.

David H. Bayley, Forces of Order: Police Behavior in Japan and the United States. P. N. Grabosky. p. 1089.

Jeanne Becquart-Leclercq, Paradoxes du pouvoir local; Peter Jambrek, Development and Social Change in Yugoslavia: Crises and Perspectives of Building a Nation; and John Walton and Louis H. Masotti, eds., The City in Comparative Perspective: Cross-National Research and New Directions in Theory. Terry Nichols Clark. p. 1090.

Gary K. Bertsch, Values and Community in Multi-National Yugoslavia. Cynthia W. Frey. p. 1091.

William Brugger, Democracy and Organisation in the Chinese Industrial Enterprise, 1948-1953. Joyce K. Kallgren. p. 1092.

Bruce Bueno de Mesquita, Strategy, Risk and Personality in Coalition Politics: The Case of India. Michael Leiserson. p. 1093.

C. W. Cassinelli, Total Revolution: A Comparative Study of Germany under Hitler, the Soviet Union under Stalin, and China under Mao. Thomas H. Greene. p. 1094.

Chan Heng Chee, The Dynamics of One Party Dominance: The PAP at the Grass Roots. Donald J. Baxter. p. 1095.

Richard P. Claude, ed., Comparative Human Rights. Lawrence J. LeBlanc. p. 1096.

Moshe M. Czudnowski, Comparing Political Behavior. Henry Teune. p. 1097.

David J. Elkins, Electoral Participation in a South Indian Context. M. Lal Goel. p. 1098.

Bruno Etienne, L'Algerie, cultures et révolution. Clement Henry Moore. p. 1099.

Ted Robert Gurr, Rogues, Rebels, and Reformers: A Political History of Urban Crime and Conflict. Douglas A. Hibbs, Jr. p. 1100.

Ted Robert Gurr, Peter N. Grabosky, and Richard C. Hula, The Politics of Crime and Conflict: A Comparative History of Four Cities. Charles Tilly. p. 1102.

Peter C. W. Gutkind and Immanuel Wallerstein, eds., The Political Economy of Contemporary Africa. Robert Melson. p. 1103.

Thomas A. Herz, Soziale Bedingungen für Rechtsextremismus in der Bundesrepublik Deutschland und in den Vereinigten Staaten. Lutz Erbring. p. 1104.

Larry B. Hill, The Model Ombudsman: Institutionalizing New Zealand's Democratic Experiment. Kent M. Weeks. p. 1105.

Fred Hirsch, Social Limits to Growth. Barry B. Hughes. p. 1106.

Peter H. Juviler, Revolutionary Law and Order: Politics and Social Change in the USSR. Donald D. Barry. p. 1107. 
Donald R. Kelley, Kenneth R. Stunkel, and Richard R. Wescott, The Economic Superpowers and the Environment: The United States, the Soviet Union, and Japan. Brian J. Katz and Leslie L. Roos, Jr. p. 1108. Martin Kilson, ed., New States in the Modern World. George Von der Muhll. p. 1109.

Jerome B. King, Law v. Order: Legal Process and Free Speech in Contemporary France. Clyde E. Jacobs. p. 1110. Kay Lawson, The Comparative Study of Political Parties. Dwaine Marvick. p. 1111.

Jacques Leruez, Economic Planning and Politics in Britain, 1945-1974. Translated by Martin Harrison. Hugh Heclo. p. 1113.

Martin Lowenkopf, Politics in Liberia: The Conservative Road to Development. J. Gus Liebenow. p. 1114.

Louis Maisel, ed., Changing Campaign Techniques: Elections and Values in Contemporary Democracies. Dan Nimmo. p. 1115.

John D. Martz and Enrique A. Baloyra, Electoral Mobilization and Public Opinion: The Venezuelan Campaign of 1973. Ronald H. McDonald. p. 1116.

Kenneth Newton, Second City Politics: Democratic Processes and Decision-Making in Burmingham. Paul E. Peterson. p. 1117.

Eric A. Nordlinger, Soldiers in Politics: Military Coups and Governments. Henry Bienen. p. 1118.

Leo Panitch, Social Democracy and Industrial Militancy: The Labour Party, the Trade Unions and Incomes Policy 1945-1974. Gerald A. Dorfman. p. 1120.

Hugh Patrick and Henry Rosovsky, eds., Asia's New Giant: How the Japanese Economy Works. John Creighton Campbell. p. 1121.

Jiri Pelikan, Socialist Opposition in Eastern Europe: The Czechoslovak Example. Translated by Marian Sling and V. and R. Tosek. Valerie Bunce. p. 1122.

Urmila Phadnis, Religion and Politics in Sri Lanka. W. Howard Wriggins. p. 1123.

Nicos Poulantzas. The Crisis of the Dictatorships: Portugal, Greece, Spain. Translated by David Fernbach. Peter Cocks. p. 1124.

Gerald Rhodes, Committees of Inquiry. James B. Christoph. p. 1125.

Paul Martin Sacks, The Donegal Mafia: An Irish Political Machine. Henry Kennedy. p. 1126.

H. Gordon Skilling, Czechoslovakia's Interrupted Revolution. George Klein. p. 1126.

Joseph Spielberg and Scott Whiteford, eds., Forging Nations: A Comparative View of Rural Ferment and Revolt. Ralph Thaxton. p. 1128.

Richard F. Staar, ed., Yearbook on International Communist Affairs: 1976. Donald R. Kelley. p. 1129.

David Stone, ed., Prelude to Self-Government: Electoral Politics in Papua New Guinea 1972. George H. Gadbois, Jr. p. 1130.

Dae-Sook Suh and Chae-Jin Lee, eds., Political Leadership in Korea. Young Whan Kihl. p. 1131.

James L. Sundquist, Dispersing Population: What America Can Learn From Europe. Kathleen Peroff. p. 1132.

Sidney Tarrow, Between Center and Periphery: Grassroots Politicians in Italy and France. Robert D. Putnam. p. 1134.

Judith V. Torney, A. N. Oppenheim, and Russell F. Farnen, Civic Education in Ten Countries: An Empirical Study. Edgar Litt. p. 1135.

Adam B. Ulam, In the Name of the People: Prophets and Conspirators in Prevevolutionary Russia. Paul Avrich. p. 1136.

Ferenc A. Vali, Politics of the Indian Ocean Region: The Balances of Power. Shahram Chubin. p. 1136.

Hendrik W. van der Merwe, ed., Looking at the Afrikaner Today; Hendrik W. van der Merwe, M. J. Ashley, N. C. J. Charton, and B. J. Huber, White South African Elites; Hendrik W. van der Merwe and C. J. Groenewald, eds., Occupational and Social Change Among Coloured People in South Africa; Hendrick W. van der Merwe and David Welsh, eds., Student Perspectives on South Africa; and Wolfgang H. Thomas, ed., Labour Perspectives on South Africa. Stanley B. Greenberg. p. 1137.

Eugen Weber, Peasants into Frenchmen: The Modernization of Rural France, 1870-1914. Peter Gourevitch. p. 1140.

Myron Weiner and John Osgood Field, eds., Electoral Politics in the Indian States. John Osgood Field and Marcus F. Franda, Volume 1: The Communist Parties of West Bengal; Jagdish N. Bhagwati, Padma Desai, John Osgood Field, William L. Richter, and Myron Weiner, Volume 2: Three Disadvantaged Sectors; John Osgood Field, Francine Frankel, Mary F. Katzenstein, and Myron Weiner, Volume 3: The Impact of Modernization; and Marguerite Ross Barnett, Craig Baxter, Paul R. Brass, Robert Hammond, Robert L. Hardgrave, Jr., and Glynn Wood, Volume 4: Party Systems and Cleavages. Shanto Iyengar. p. 1141.

James W. Wilkie, Michael C. Meyer, and Edna Monzón de Wilkie, eds., Contemporary Mexico: Papers of the IV International Congress of Mexican History. Felix G. Boni. p. 1142.

Harold Wilson, The Governance of Britain. Jorgen S. Rasmussen. p. 1144.

Crawford Young, The Politics of Cultural Pluralism. Robert H. Bates. p. 1145.

\section{International Politics}

Olajide Aluko, Ghana and Nigeria 1957-70: A Study in Inter-African Discord. Victor A. Olorunsola. p. 1146.

A. Doak Bamett, China Policy: Old Problems and New Challenges. June Teufel Dreyer. p. 1147.

John H. Barton and Lawrence D. Weiler, eds., International Arms Control: Issues and Agreements. Joseph Kruzel. p. 1149. 
Istvan Bibo, The Paralysis of International Institutions and the Remedies: A Study of Self-Determination, Concord Among the Major Powers, and Political Arbitration. William A. Hazleton. p. 1150.

Joseph A. Camilleri, Civilization in Crisis: Human Prospects in a Changing World. Louis René Beres. p. 1151.

Nazli Choucri with Vincent Ferraro, International Politics of Energy Interdependence: The Case of Petroleum. Dankwart A. Rustow. p. 1152.

Cal Clark and Robert L. Farlow, Comparative Patterns of Foreign Policy and Trade: The Communist Balkans in International Politics. Zvi Gitelman. p. 1153.

Andrew W. Cordier and Max Harrelson, eds., Public Papers of the Secretaries-General of the United Nations, Volume 6: U Thant 1961-1964. Robert S. Wood. p. 1154.

Richard W. Cottam, Foreign Policy Motivation: A General Theory and a Case Study. Robert C. North. p. 1155.

Harold Eugene Davis, Larman C. Wilson, and others, Latin American Foreign Policies: An Analysis. Federico G. Gil. p. 1157.

I. M. Destler, Priscilla Clapp, Hideo Sato, and Haruhiro Fukui, Managing an Alliance: The Politics of U.S. Japanese Relations. Tsutomu Odani. p. 1158.

Werner J. Feld, The European Community in World Affairs: Economic Power and Political Influence. Farzeen Nasri. p. 1159.

Galia Golan, Yom Kippur and After: The Soviet Union and the Middle East Crisis. John A. Armstrong. p. 1160.

Leon Gordenker, International Aid and National Decisions: Development Programs in Malawi, Tanzania, and Zambia. Harold K. Jacobson. p. 1161.

William E. Griffith, ed., The World and the Great-Power Triangles. Jacek Kugler. p. 1162.

Morton A. Kaplan and Kinhide Mushakoji, eds., Japan, America, and the Future World Order. Young C. Kim. p. 1163.

Gavin Kennedy, The Economics of Defence. Paul Y. Hammond. p. 1164.

Robert O. Keohane and Joseph S. Nye, Power and Interdependence: World Politics in Transition. David A. Baldwin. p. 1165.

Douglas Kinnard, The War Managers. Lee Sigelman. p. 1168.

Klaus Knorr, ed., Historical Dimensions of National Security Problems. Charles A. Raith. p. 1169.

Werner Levi, Law and Politics in the International Society. Clifton E. Wilson. p. 1170.

George Liska, Quest for Equilibrium: America and the Balance of Power on Land and Sea. David W. Tarr. p. 1171.

Richard Lowenthal, Model or Ally? The Communist Powers and the Developing Countries. Carl F. Pinkele. p. 1172.

Gerhard Mally, Interdependence: The European-American Connection in the Global Context. Elliot $\mathbf{R}$. Goodman. p. 1173.

Laurence Martin, ed., The Management of Defence. Davis B. Bobrow. p. 1174.

Onkar Marwah and Ann Schulz, eds., Nuclear Proliferation and the Near-Nuclear Countries. Alan Dowty. p.1175.

Baldev Raj Nayar, American Geopolitics and India. Norman D. Palmer. p. 1177.

Eugenia V. Nomikos and Robert C. North, International Crisis: The Outbreak of World War I. Paul W. Schroeder. p. 1177.

William W. Orbach, To Keep the Peace: The United Nations Condemnatory Resolution. Gary B. Ostrower. p. 1179.

Lewis McCarroll Purifoy, Harry Truman's China Policy: McCarthyism and the Diplomacy of Hysteria, 1947-1951. Sheldon Appleton. p. 1180.

W. Michael Reisman and Burns H. Weston, eds., Toward World Order and Human Dignity: Essays in Honor of Myres S. McDougal. Don C. Piper. p. 1181.

Richard B. Remnek, Soviet Scholars and Soviet Foreign Policy: A Case Study in Soviet Policy towards India. Richard L. Siegel. p. 1182.

Richard Rosecrance, ed., America as an Ordinary Country: U.S. Foreign Policy and the Future; and Francis 0. Wilcox and Richard A. Frank, eds., The Constitution and the Conduct of Foreign Policy. James R. Kurth. p. 1183.

Dankwart A. Rustow and John F. Mugno, OPEC: Success and Prospects. Edward E. Azar. p. 1184.

John G. Stoessinger, Henry Kissinger: The Anguish of Power; and Bruce Mazlish, Kissinger: The European Mind in American Policy. Stephen G. Walker. p. 1185.

John P. Vloyantes, Silk Glove Hegemony: Finnish-Soviet Relations, 1944-1974-A Case Study of the Theory of the Soft Sphere of Influence. Karen Erickson Örvik. p. 1186.

Helen Wallace, William Wallace, and Carole Webb, eds., Policy-Making in the European Communities. John Starrels. p. 1187.

Franklin B. Weinstein, Indonesian Foreign Policy and the Dilemma of Dependence: From Sukarno to Soeharto. Donald G. McCloud. p. 1188.

Phil Williams, Crisis Management: Confrontation and Diplomacy in the Nuclear Age. William R. Kintner. p.1189.

Dina A. Zinnes, Contemporary Research in International Relations: A Perspective and a Critical Appraisal. Michael D. Wallace. p. 1191 . 
Just published...

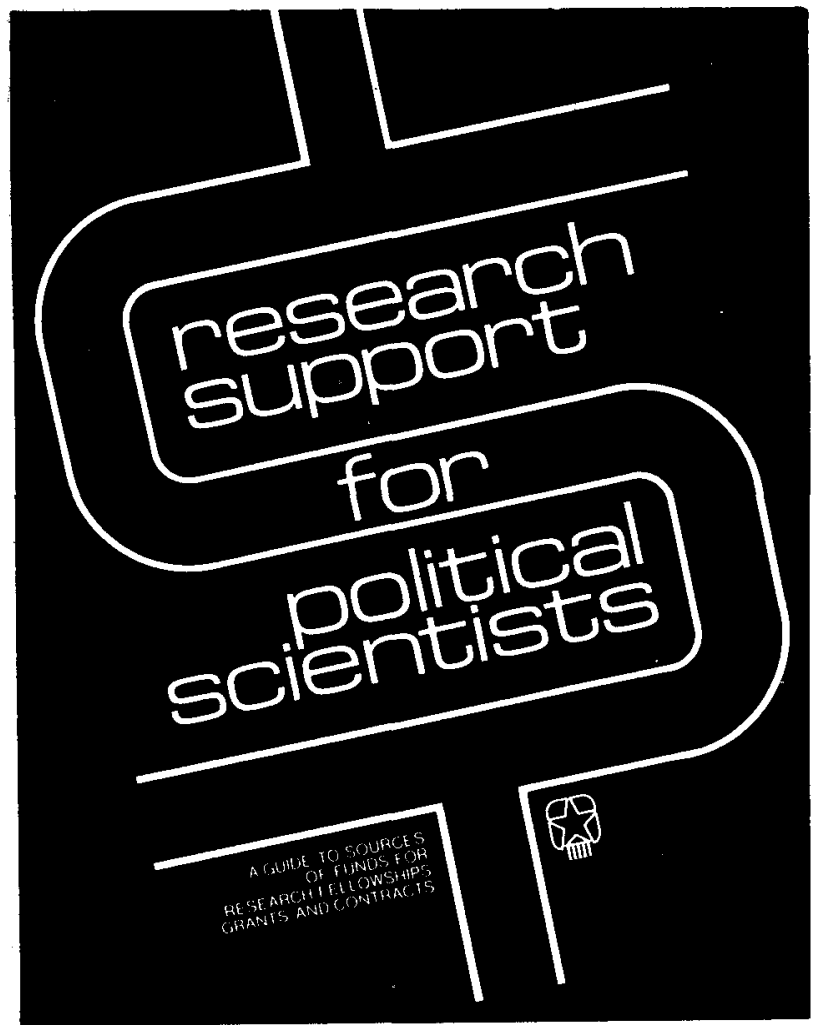

ORDER FORM

Please send me copies of Research Support for Political Scientists.

Enclosed is my check for $\$$ to cover the cost at $\$ 4.00$ each.

Name

Address

Zip

All orders must be prepaid.

Return to:

The American Political Science Association

1527 New Hampshire Avenue, N.W.

Washington, D.C. 20036 


\title{
The American Political Science Association
}

\author{
1527 New Hampshire Avenue, N.W., Washington, D.C. 20036
}

PRESIDENT: John C. Wahlke, University of Iowa; PRESIDENT-ELECT: Leon D. Epstein, University of Wisconsin; VICE PRESIDENTS: Joyce K. Kallgren, University of California, Davis; Charles E. Lindblom, Yale University; Donald E. Stokes, Princeton University; SECRETARY: Randall B. Ripley, Ohio State University; TREASURER: Dina A. Zinnes, Indiana University; PROGRAM CHAIRPERSON: Elinor Ostrom, Indiana University; EXECUTIVE DIRECTOR: Evron M. Kirkpatrick; MANAGING EDITOR, APSR: Charles O. Jones, University of Pittsburgh.

COUNCIL: (Above-named Officers ex officiis), 1977-1979: Marguerite Ross Barnett, Howard University; Robert T. Holt, University of Minnesota; Martin Landau, University of Califormia, Berkeley; David R. Mayhew, Yele University; Robert D. Putnam, University of Michigan; Clement E. Vose, Wesleyan University; James Q. Wilson, Harvard University; Betty H. Zisk, Boston University; 1978-1980: Peter Bachrach, Temple University; Richard A. Brody, Stanford University; Doris A. Graber, University of Illinois, Chicago Circle; Erwin C. Hargrove, Vanderbilt University; Sanford A. Lakoff, University of California, San Diego; Sarah McCally Morehouse, University of Connecticut, Stamford; Alan Rosenthal, Rutgers University; Ellis Sandoz, East Texas State University.

FORMER PRESIDENTS: Frank J. Goodnow, Albert Shaw, Frederic N. Judson, James Bryce, A. Lawrence Lowell, Woodrow Wilson, Simeon E. Baldwin, Albert Bushnell Hart, W. W. Willoughby, John Bassett Moore, Ernst Freund, Jesse Macy, Munroe Smith, Henry Jones Ford, Paul S. Reinsch, Leo S. Rowe, William A. Dunning, Harry A. Garfield, James W. Garner, Charles E. Merriam, Charles A. Beard, William B. Munro, Jesse S. Reeves, John A. Fairlie, Benjamin F. Shambaugh, Edward S. Corwin, William F. Willoughby, Isidor Loeb, Walter J. Shepard, Francis W. Coker, Arthur N. Holcombe, Thomas Reed Powell, Clarence A. Dykstra, Charles Grove Haines, Robert C. Brooks, Frederic A. Ogg, William Anderson, Robert E. Cushman, Leonard D. White, John M. Gaus, Walter F. Dodd, Arthur W. Macmahon, Henry R. Spencer, Quincy Wright, James K. Pollock, Peter H. Odegard, Luther H. Gulick, Pendleton Herring, Ralph J. Bunche, Charles McKinley, Harold D. Lasswell, E. E. Schattschneider, V. O. Key, Jr., R. Taylor Cole, Carl B. Swisher, Emmette S. Redford, Charles S. Hyneman, Carl J. Friedrich, C. Herman Pritchett, David B. Truman, Gabriel A. Almond, Robert A. Dahl, Merle Fainsod, David Easton, Karl W. Deutsch, Robert E. Lane, Heinz Eulau, Robert E. Ward, Avery Leiserson, Austin Ranney, James MacGregor Burns, Samuel H. Beer.

MEMBERSHIP INFORMATION: The American Political Science Review, published quarterly during the months of March, June, September, and December, is supplied to all APSA members. Membership dues are charged according to the following schedule:

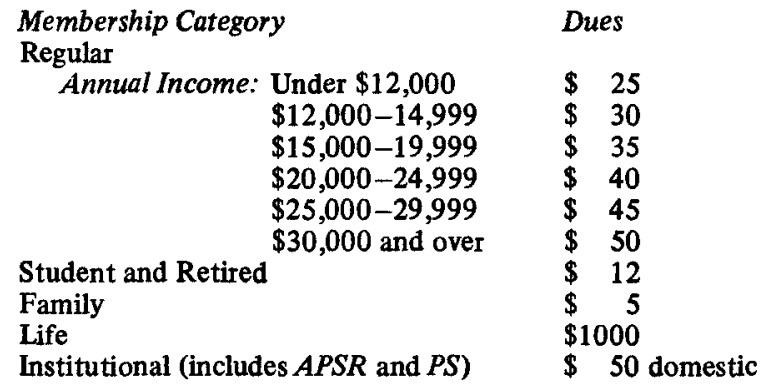

Student memberships are limited to five years per person. Foreign currency at the official exchange rate will be accepted for foreign subscriptions and foreign membership fees. The equivalent of $\$ 3$ per year for additional postage should be added for foreign subscriptions.

Current issues are priced at $\$ 10.50$ per copy; for back issues prior to 1970 address Walter J. Johnson, Inc., 355 Chestnut St., Norwood, New Jersey 07648; for issues 1970 and later send request directly to the American Political Science Association.

Applications for membership, orders for the Review, and remittances should be addressed to the Executive Director, The American Political Science Association, 1527 New Hampshire Ave., N.W., Washington, D.C. 20036. Notices of change of address should be received in the Washington office by the 25th day of the months before publication.

INDEXING: Articles and notes appearing in the Review before the June 1953 issues were indexed in The Reader's Guide to Periodical Literature. Current issues are indexed by The International Political Science Abstracts, the United States Political Science Documents, and the Social Sciences and Humanities Index. Microfilm of the Review, beginning with Volume 1, may be obtained from University Microfilms, 313 North First Street, Ann Arbor, Michigan 48106. A Cumulative Index of the Review, Volumes 1-62;1906-1968, may also be obtained from University Microfilms. Articles appearing in the Review are listed regularly in $A B C P O L S c i$ and Current Contents: Behavioral, Social \& Management Sciences. Book reviews are indexed in Book Review Index. 


\title{
The American Political Science Review
}

\author{
Department of Political Science, University of Pittsburgh \\ Pittsburgh, Pennsylvania 15260
}

EDITORIAL BOARD: Charles O. Jones, Managing Editor, University of Pittsburgh; Robert M. Axelrod, University of Michigan; Carl Beck, University of Pittsburgh; Steven J. Brams, New York University; Richard A. Brody, Stanford University; William J. Daniels, Union College; Ada W. Finifter, Michigan State University; Dante Germino, University of Virginia; J. Woodford Howard, Johns Hopkins University; George A. Kateb, Amherst College; Henry C. Kenski, University of Arizona; Nannerl O. Keohane, Stanford University; Anthony King, University of Essex; Gerald H. Kramer, Yale University; Arend Lijphart, University of Leiden; Jesse J. McCorry, Washington University; Joseph L. Nogee, University of Houston; Elinos Ostrom, Indiana University; Samuel C. Patterson, University of Iowa; Nelson W. Polsby, University of California, Berkeley; Kenneth Prewitt, National Opinion Research Center; Jorgen S. Rasmussen, Iowa State University; Donald D. Searing, University of North Carolina; James L. Sundquist, The Brookings Institution; Henry Teune, University of Pennsylvania; Edward R. Tufte, Yale University; Susan Welch, University of Nebraska; Dina A. Zinnes, Indiana University. EDITORIAL ASSISTANT: Kendall S. Stanley.

BOOK REVIEW EDITORIAL BOARD: Paul Allen Beck, Book Review Editor, University of Pittsburgh; Jeane J. Kirkpatrick, American Enterprise Institute; James R. Kurth, Swarthmore College; J. Donald Moon, Wesleyan University; James C. Scott, Yale University. EDITORLAL ASSISTANT: Sabina Bilder.

\section{MANUSCRIPT EDITOR: Jane Flanders.}

EDITORIAL INTERNS: Hizkias Assefa, Cary N. Bloyd, Gerard M. Gallucci, Richard K. Hermann, Ernesto Isuani, Austin Linsley, Gary Mucciarone, Kevin Neary, Constance E. Rea, Lewis M. Stern, J. Christopher Walker, Mark Winer.

\section{INSTRUCTIONS TO CONTRIBUTORS}

Address correspondence about contributions to the Review to Charles O. Jones, American Political Science Review, Department of Political Science, University of Pittsburgh, Pittsburgh, Pennsylvania 15260. Please submit four copies of a manuscript to be considered for publication. Unfortunately, due to increased postage costs, we can no longer return manuscripts to the author. Manuscripts must be typed and mimeographed or photocopied, with all written material double-spaced (including quotations and footnotes) Use standard typewriter paper-avoid colored and light-weight stock. The typewritten lines should not exceed $5 \frac{1}{2}$ or 6 inches in length. Please do not send the original typescript. Since manuscripts are sent out anonymously for evaluation, the author's name and affiliation should appear only on a separate covering sheet. An abstract of less than 150 words should accompany the manuscript.

The footnote form is that used by most scientific journals. Explanatory notes only will be permitted for most manuscripts (see below); references will be listed alphabetically at the end of the manuscript; and in-text references will be made by inserting author or title, year, and page number, if appropriate. For illustration see Fred I. Greenstein and Nelson W. Polsby, eds., Handbook of Political Science (Reading, Mass.: Addison-Wesley, 1975). Note: Authors of manuscripts on the history of political thought may, if they prefer, use the traditional footnote form when referring to the individual theorist's work; the reference form should be used when referring to secondary works.

All manuscripts will be examined carefully for length. Referees will be asked to recommend where cuts might be made, without affecting the principal contribution. Manuscripts over 30 pages will be reviewed with particular care to determine if such length is warranted. Except in extraordinary circumstances, manuscripts over 50 pages will be returned to the author. Resubmission may follow compliance with the page limit. Manuscripts must be prepared as noted above, double-spaced throughout, with standard margins. Tables, charts, footnotes, and references will be included in the page count.

Communications must follow the form of regular manuscripts (including reference listings where appropriate). They must not exceed five double-spaced pages, including references, footnotes, and tables. All but the briefest letters will be refereed.

Figures should be drawn on white paper with India ink and the original tracings or drawings retained by the author (for transmission later to the printer). Copies only should accompany the manuscript. Tables should be typed on a separate page. Insert a guide line, e.g., "Table 1 about here," at the appropriate place in the manuscript.

Books intended for review and all book review correspondence should be sent to Paul A. Beck, Book Review Editor, American Political Science Review, Department of Political Science, University of Pit tsburgh, Pittsburgh, Pennsylvania 15260. Authors are urged to call their books to the attention of the Book Review Editor to insure that the books will be considered for review.

Information, including News and Notes, for the Association's news-journal, PS, should be sent to 1527 New Hampshire Avenue, N.W., Washington, D.C. 20036. Advertising, reprint and circulation correspondence should be sent to the Executive Director at the Washington office. Domestic claims for non-receipt of issues must be made within six months of the month of publication; overseas claims, one year. Advertising information and rates are available from Elizabeth E. Horton, Advertising Manager, APSA, 1527 New Hampshire Avenue, N.W., Washington, D.C. 20036. 